Antonio Carlos Nascimento

Simone Tetu Moysés

Julio Cesar Bisinelli

Samuel Jorge Moysés

Programa de Pós-Graduação em Odontologia Pontifícia Universidade Católica do Paraná.

Curitiba, PR, Brasil

Correspondence:

Antonio Carlos Nascimento

Universidade Positivo, Curso de Odontologia

R. Prof. Pedro V. Parigot de Souza, 5300

Campo Comprido

81280-330 Curitiba, PR, Brasil

E-mail: antonioc@up.edu.br

\section{Oral health in the family health strategy: a change of practices or semantics diversionism}

\section{Saúde bucal na estratégia de saúde da família: mudança de práticas ou diversionismo semântico}

\begin{abstract}
OBJECTIVE: To evaluate public health dentistry practices of two different family health models.

METHODS: Qualitative study conducted with data obtained from focus groups consisting of 58 dentists working in the Family Health Strategy for at least three years between August-October, 2006. The Paideia Family Health Approach was used in the city of Campinas and the Oral Health Initiative as part of the Family Health Strategy was implemented in the city of Curitiba, Southeastern and Southern Brazil, respectively. Data was analyzed using the hermeneutic-dialectic method. Analysis indicators were employed to indicate backwardness, stagnation or progress in oral health practices effective from the implementation of the strategies referred. The indicators used were: work process; interdisciplinary approach; territorialization; capacity building of human resources; health promotion practices; and responsiveness to users' demands.
\end{abstract}

RESULTS: There was progress in user access to services, humanization of health care, patient welcoming and patient-provider relationship. The results related to health promotion practices, territorialization, interdisciplinary approach and resource capacity building indicated a need for technical and operational enhancements in both cities.

CONCLUSIONS: Both models have brought about important advances in terms of increased access to services and humanization of health care. Universal access to oral health at all levels of complexity was not achieved in both cities studied. Local health managers and oral health program coordinators must bring more weight to bear in the arena that defines public policy priorities.

DESCRIPTORS: Oral Health. Family Health. Comprehensive Dental Care. Program Evaluation. Health Services Evaluation. Qualitative Research. 


\section{RESUMO}

OBJETIVO: Avaliar práticas de saúde bucal coletiva de dois modelos de atenção à saúde familiar.

MÉTODOS: Estudo qualitativo realizado por meio de grupos focais constituídos por 58 cirurgiões-dentistas atuantes em programa de saúde da família há pelo menos três anos. Foram adotados os modelos de atenção Método Paidéia em Saúde da Família (Campinas, SP, 34 profissionais) e Estratégia de Saúde da Família (Curitiba, PR, 24 profissionais). O estudo foi realizado entre os meses de agosto e outubro de 2006. O referencial teórico utilizado para análise dos dados foi a hermenêutica-dialética. Foram empregados indicadores analíticos visando a indicar retrocesso, estagnação ou progresso nas práticas de saúde bucal que tiveram efeito a partir da implantação das estratégias em estudo. Os indicadores utilizados foram: processo de trabalho, interdisciplinaridade, territorialização, qualificação dos trabalhadores, promoção da saúde, resolutividade às demandas dos usuários.

RESULTADOS: Houve progresso no acesso dos usuários aos serviços, na humanização do cuidado em saúde, no acolhimento das pessoas e no vínculo entre os profissionais e os pacientes. Os resultados relativos às práticas de promoção de saúde, territorialização, abordagem interdisciplinar e qualificação das equipes indicaram a necessidade de avanços técnicos e operacionais nas duas cidades.

CONCLUSÕES: Os dois modelos apresentam importantes avanços na qualificação do acesso e na humanização do cuidado em saúde. Não obstante, o direito universal ao acesso à saúde bucal, em todos os níveis de complexidade, mostrou-se deficiente nas duas cidades. Os gestores locais dos serviços de saúde e os coordenadores municipais de saúde bucal, devem atuar com maior intensidade ao definir prioridades em políticas públicas de saúde local.

DESCRITORES: Saúde Bucal. Saúde da Família. Assistência Odontológica Integral. Avaliação de Programas e Projetos de Saúde. Avaliação de Serviços de Saúde. Pesquisa Qualitativa.

\section{INTRODUCTION}

Research on the performance of initiatives based on the Family Health Strategy (FHS), such as the Paideia Family Health Approach used in Campinas and the Oral Health Initiative as part of the FHS in Curitiba, is very relevant. Both initiatives have a major impact in the arena of Brazilian public health policies, particularly in the basic health care scenario following the 1988 Brazilian Constitution.

The main thematic issue of the present study is to assess changes in oral health practices following the implementation of the FHS in two Brazilian cities. It could be that political and administrative forces have contributed to the expansion of the changes desired, or either that the original essential proposal may have been disfigured.

The first Brazilian programmatic dental policy was developed in the $1950 \mathrm{~s}^{7}$ and targeted exclusively at schoolchildren, and has become enrooted nationwide.
From then on, over time and after many different "dental labeling" public oral health policies ${ }^{14}$ have advanced and Public Health Dentistry (PHD) has finally become reality in the $21^{\text {st }}$ century.

Borrowing its name from Campos's publication, ${ }^{3} \mathrm{PHD}$ seeks to engage in "public Health and defense of life". Defending life with generosity involves taking into consideration people's oral health as part of a social project whereby smiling and speaking do not cause embarrassment and pain to the orally mutilated. PHD supports contextualized and transforming practices that break off with the hegemonic dental mercantilism, ${ }^{14}$ and follows principles that lead to oral health strengthening within the Brazilian National Health System (Sistema Único de Saúde, SUS).

The Paideia Family Health Approach in Campinas, Southeastern Brazil, has been developed to redirect health practices. The reform sought to create shared 
management based on both technical and popular knowledge, emphasizing the concept of a broader clinical approach, centered on the human being. ${ }^{4}$ It is different from "clinical practice debased by pronounced power imbalances", ${ }^{4}$ permeated with alienated professional procedures, which treat cases in a manner removed from individual patient needs. The definite implementation of Paideia Approach occurred within an active process involving building capacity and awareness raising of human resources. ${ }^{1,4} \mathrm{Up}$ until the year 2000 , oral health services in Campinas were organized according to the traditional public health programs and with emphasis in the meeting of perceived urgent oral health problems. Low resolutivity and a bureaucratic management model made the population's access to services difficult at the end of the 1990s. The Paideia Method of Family Health reoriented the oral health practices model, following the new general health principles in Campinas.

The expansion of health services in Curitiba, Southern Brazil, occurred parallel to an active process involving the claiming of citizen's rights in Brazil, including the right to health, culminating in the 1988 Brazilian Constitution and SUS implementation. In effect since mid-1980s, the basic health network has increased access to working class people by operating at night. With regard to dental services, an active process of changes of the former care model targeting schoolchildren has been initiated, and there has been a concern to include population without access to these services. Curitiba's Health Plan involved the implementation of the Integrated Health Service System (IHSS), reinforcing the importance of being population-centered, including health surveillance and giving particular emphasis on situations of social/family fragility. The IHSS was based on three pillars: evidence-based clinical care, economic evaluation, and critical evaluation of health technology incorporation. ${ }^{11}$

In order to compare the health systems in the two cities, the demographic information, structure of the basic attention in PHD, human resorts and data on caries prevalence [DMF-T at 12 year] are shown in the Table 1. Also, information on the monetary health resources in the two cities are shown in the Table 2.

The objective of the present study was to evaluate changes in oral health practices after the implementation of two primary family health care models.

\section{METHODS}

A qualitative study was conducted with data obtained from focus groups, ${ }^{9}$ consisting of 58 dentists working in the FHS in the two cities studied (34 providers in Campinas and 24 in Curitiba, Southeast and Southern Brazil, respectively) between August an October in 2006.

Table 1. Demographic information, public health dentistry structure, human resources and mean number of decayed, missing or filled permanent teeth. Campinas and Curitiba, Southeastern and Southern Brazil, 2007.

\begin{tabular}{|c|c|c|c|c|c|c|c|c|}
\hline City & Population & $\begin{array}{l}\text { Medical } \\
\text { center }\end{array}$ & $\begin{array}{l}\text { Dental } \\
\text { clinics }\end{array}$ & $\begin{array}{c}\text { Health centers } \\
\text { with FHS }\end{array}$ & $\begin{array}{c}\text { Dental specialty } \\
\text { centers }\end{array}$ & $\begin{array}{c}\text { Oral } \\
\text { health HR }\end{array}$ & $\begin{array}{c}\text { SUS dental } \\
\text { surgeon/inhabitant }\end{array}$ & DMF-T \\
\hline Campinas & $1,059,420$ & 49 & 49 & 61 teams & 1 & $\begin{array}{l}254 \mathrm{DS} \\
132 \mathrm{DA} \\
20 \mathrm{DH}\end{array}$ & $1 / 4170$ & 1.34 \\
\hline Curitiba & $1,788,559$ & 110 & 95 & 115 teams & 2 & $\begin{array}{l}502 \mathrm{DS} \\
488 \mathrm{DA} \\
182 \mathrm{DH}\end{array}$ & $1 / 3657$ & 1.27 \\
\hline
\end{tabular}

Source: Brazilian Institute of Geography and Statistics (Instituto Brasileiro de Geografia e Estatística, IBGE). Brazilian population projection: 1980-2050. [cited Mar 5]. Available from: http://www.ibge.gov.br/home/estatistica/populacao/ projecao_da_populacao/default.shtm

FHS: Family Health Strategy

HR: Human resources

SUS: Brazilian National Health System

DMF-T: Mean number of decayed, missing and filled permanent teeth at 12 years of age;

DS: Dentists

DA: Dental assistants

$\mathrm{DH}$ : Dental hygienists

Table 2. Total resources in health, their origin and percentage allocated to oral health in Campinas and Curitiba, Southeastern an Southern Brazil, 2006.

\begin{tabular}{lcccc}
\hline Local budget $(\mathrm{R} \$)$ & $\begin{array}{c}\text { Allocated to health } \\
\text { care }(\mathrm{R} \$ \text { and } \%)\end{array}$ & $\begin{array}{c}\text { \% own resources in } \\
\text { health }\end{array}$ & $\begin{array}{c}\text { \% health resources from } \\
\text { intergovernmental funding }\end{array}$ & $\begin{array}{c}\text { \% local health funds } \\
\text { allocated to oral health }\end{array}$ \\
\hline $1,695,487,187$ & $342,036,987(30.3)$ & 64.0 & 36.0 & $4.97^{\text {a }}$ \\
$2,549,640,000$ & $515,216,000(20.2)$ & 30.8 & 69.1 & Unknown $^{2}$ \\
\hline
\end{tabular}

\footnotetext{
${ }^{a}$ Budget for human resources included
} 
The participant selection criterion was being a female or male dentist who has been working in the FHS for at least three years. The selection of participants was directed and intentional and subjects with greater experience in working in these programs were selected to obtain the most qualified information. ${ }^{8}$

In order to focus on the proposed variables, a sequence of discussion points was followed to conduct focus group discussions. ${ }^{9,12}$ The main characteristic of the focus groups was the explicit use of participant interaction to produce data and insights which otherwise could not be accessed through non-interactive processes. The sessions were recorded and then fully transcribed.

Data handling was based on the premise that the researcher should not allow prior value judgments to interfere with the matter being studied. The analysis was based on the hermeneutic-dialectic method ${ }^{12}$ and sought to avoid what Bordieu, quoted by Minayo, ${ }^{12}$ referred as the "illusion of transparency," i.e., an attempt to spontaneously interpret the data as if they were true and complete at the researcher's first superficial glance.

Session transcriptions were compared within and between the groups to check for trends towards backwardness, stagnation or progress of PHD practices. The indicators studied, inductive questions, and the level of model development are shown in Table 3.
The study was approved by the Research Ethics Committee of Secretaria Municipal da Saúde de Curitiba (Report No. 03/2006), and with the agreement of Secretaria Municipal da Saúde de Campinas. All subjects signed a free and informed consent form.

\section{RESULTS}

A summary of the study results according to the analytic process is presented in Table 4.

\section{Differentiation in public health dentistry practices}

The groups studied in Campinas and Curitiba showed that a new modus operandi in PHD was emerging.

In Campinas, the main finding was the reduction of obstacles to user access. The discourses suggested that health teams present themselves as accessible and understanding, which was the opposite of the existing situation prior to the FHS implementation:

"When we started this new model here in Campinas we felt as if a bomb had fallen on us, [...] sometimes we wanted to say, "Stop community health workers! Please don't bring anything else new, it's too much!." The problems already existed, but they were not apparent, they only became visible [...] after opening up for the community to come in but there's no turning back" (camp30)

Table 3. Indicators, inductive questions and level of development of the oral health model studied. Campinas and Curitiba, Southeastern and Southern Brazil, 2006.

\begin{tabular}{|c|c|c|c|c|}
\hline \multirow[b]{2}{*}{ Indicator } & \multirow[b]{2}{*}{ Inductive question } & \multicolumn{3}{|c|}{ Level of model development } \\
\hline & & $\begin{array}{c}\text { Basic/ } \\
\text { undesirable }\end{array}$ & Intermediate & Advanced/desirable \\
\hline $\begin{array}{l}\text { 1. Changes in oral } \\
\text { health practices }\end{array}$ & $\begin{array}{c}\text { Any difference between working } \\
\text { in a conventional health center } \\
\text { and the Paideia/FHS? }\end{array}$ & No change & Evidence of change & $\begin{array}{l}\text { Model reoriented } \\
\text { towards PHD practices }\end{array}$ \\
\hline $\begin{array}{l}\text { 2. Interdisciplinary } \\
\text { work process }\end{array}$ & $\begin{array}{c}\text { What is teamwork like in your } \\
\text { health center? }\end{array}$ & $\begin{array}{l}\text { No integration } \\
\text { at all }\end{array}$ & $\begin{array}{l}\text { Multidisciplinary } \\
\text { integration (clinics) }\end{array}$ & $\begin{array}{l}\text { Interdisciplinary } \\
\text { integration }\end{array}$ \\
\hline 3. Territorialization & $\begin{array}{l}\text { Is there a working territory? } \\
\text { How does it affect care? }\end{array}$ & $\begin{array}{c}\text { Territory is } \\
\text { bureaucratic } \\
\text { and restricts } \\
\text { access }\end{array}$ & $\begin{array}{l}\text { Territory has a social } \\
\text { process of intervention, } \\
\text { but access is limited }\end{array}$ & $\begin{array}{l}\text { Territory involves } \\
\text { a social process of } \\
\text { intervention and } \\
\text { access is not restricted }\end{array}$ \\
\hline $\begin{array}{l}\text { 4. Training process } \\
\text { for the new model }\end{array}$ & $\begin{array}{l}\text { The health department holds } \\
\text { training sessions for the Paideia/ } \\
\text { FHS models? }\end{array}$ & $\begin{array}{l}\text { Low } \\
\text { institutional } \\
\text { investment }\end{array}$ & $\begin{array}{l}\text { Average institutional } \\
\text { investment }\end{array}$ & $\begin{array}{c}\text { Adequate institutional } \\
\text { investment }\end{array}$ \\
\hline $\begin{array}{l}\text { 5. Use of health } \\
\text { promotion } \\
\text { practices }\end{array}$ & $\begin{array}{c}\text { Health promotion as important } \\
\text { for reorienting basic health care. } \\
\text { How do you evaluate it? }\end{array}$ & $\begin{array}{l}\text { Failure to } \\
\text { understand } \\
\text { the concept } \\
\text { and its } \\
\text { applicability }\end{array}$ & $\begin{array}{l}\text { Understanding of the } \\
\text { concept, but with } \\
\text { operational difficulties } \\
\text { in its application }\end{array}$ & $\begin{array}{l}\text { Understanding of } \\
\text { the concept and } \\
\text { efforts to apply it to } \\
\text { clinical practice and } \\
\text { intersectorally in the } \\
\text { territory }\end{array}$ \\
\hline $\begin{array}{l}\text { 6. Ability to } \\
\text { respond to user's } \\
\text { demands }\end{array}$ & $\begin{array}{c}\text { What is the ability to resolve } \\
\text { health complaints of service } \\
\text { users like? }\end{array}$ & $\begin{array}{l}\text { Team does } \\
\text { not seek to } \\
\text { resolve users' } \\
\text { complaints }\end{array}$ & $\begin{array}{c}\text { Team welcomes the } \\
\text { user, makes a note of } \\
\text { his/her complaints, but } \\
\text { is unable to resolve } \\
\text { them }\end{array}$ & $\begin{array}{l}\text { Team welcomes the } \\
\text { user, makes a note of } \\
\text { his/her complaints and } \\
\text { is able to resolve them }\end{array}$ \\
\hline
\end{tabular}


Table 4. Levels of model development. Campinas and Curitiba, Southeastern and South Southeastern Brazil, 2006.

\begin{tabular}{|c|c|c|}
\hline \multirow{2}{*}{ Indicator } & \multicolumn{2}{|c|}{ Level of development } \\
\hline & Campinas & Curitiba \\
\hline \multicolumn{3}{|l|}{ 1. Differentiation in PHD } \\
\hline 1.1. Bond & Advanced & Advanced \\
\hline 1.2. Humanization & Advanced & Advanced \\
\hline 1.3. Access & Advanced & Advanced \\
\hline $\begin{array}{l}\text { 1.4. Individuals' } \\
\text { autonomy }\end{array}$ & Advanced & $\begin{array}{l}\text { Not } \\
\text { reported }\end{array}$ \\
\hline 1.5. Prioritization by risks & Advanced & Advanced \\
\hline 1.6. Local planning & Advanced & \\
\hline $\begin{array}{l}\text { 2. Interdisciplinary work } \\
\text { processes }\end{array}$ & Intermediate & Intermediate \\
\hline $\begin{array}{l}\text { 3. Working in a territorial } \\
\text { base }\end{array}$ & Intermediate & $\begin{array}{l}\text { Intermediate } \\
\text { to advanced }\end{array}$ \\
\hline $\begin{array}{l}\text { 4. Institutional development } \\
\text { of model training }\end{array}$ & Basic & Basic \\
\hline $\begin{array}{l}\text { 5. Application of health } \\
\text { promotion practices }\end{array}$ & $\begin{array}{l}\text { Basic to } \\
\text { intermediate }\end{array}$ & $\begin{array}{l}\text { Basic to } \\
\text { intermediate }\end{array}$ \\
\hline $\begin{array}{l}\text { 6. Ability to respond to user } \\
\text { needs }\end{array}$ & $\begin{array}{l}\text { Basic to } \\
\text { intermediate }\end{array}$ & $\begin{array}{c}\text { Basic to } \\
\text { intermediate }\end{array}$ \\
\hline
\end{tabular}

PHD: Public Health Dentistry

The humanization of health care was another factor of differentiation evidenced in both cities. Another change was the perception of the user being more than just an anonymous person with a oral health complaint and being rather an individual within a social context which determined to greater or lesser degree his or her vulnerability to diseases:

"Patients would get here at 4 am, they would have to sit and wait until 7 am when they got a number to wait in line [...] sometimes they would still be waiting to be seen at $3 \mathrm{pm}$. After all this suffering, all they needed was to be referred to an X-ray. I find that inhumane. That's the way it was and nobody questioned it. I think the Paideia Approach has considerably improved the humanization of the service provided" (camp19).

And Curitiba:

"I think there's an epidemiological view of the healthdisease process. Take the case of bacterial plaque, which is so specific. We go beyond the individual and focus on other determinants of this problem, even social and cultural issues are involved. For me it was a big change. We begin to see how an individual lives, his or her relationship with the family and community, and all this related to health problems. I believe we no longer see the mouth separated from the rest of the body nor the body separated from the environment the individual lives in" (ctba20)

Campinas showed singular changes compared to the reality experienced prior to the Paideia Approach was implemented in 2001. For example, greater autonomy of basic health center teams to undertake local planning, bringing the working process into line with the particularities of each community, and giving emphasis to the care of the most vulnerable people. This approach reflected the understanding of the individual made different by the social context:

"I think that in the Family Health Program you have to understand the role of a given family in the territory. We have to prioritize what is the most serious in an already serious situation. We have to take into account social and cultural issues of that population" (camp13).

\section{Interdisciplinary approach}

In Campinas and Curitiba clinical interaction between teams was evident, although Curitiba showed that, in addition to clinical exchange, there was also interaction between them to intervene in social and environmental disease determinants:

"Teamwork is not only social integration and clinical referral; it is integration to respond to priority cases and problems" (ctba3)

In the Paideia Approach the interrelationship between technical knowledge and reciprocal patient referral had brought progress in health care:

"I think we've got better access now pediatricians check inside the mouth which they didn't use to do, they refer patients [...] I used to joke that the mouth was the 'black hole' of public health.” (camp12)

\section{Working within a territorial base}

The groups showed deep conceptual knowledge about working within territories. In practical terms, however, they noted operational limitations.

In Campinas, the greatest obstacle to working within territories was the huge demand arising from clinical cases at basic health centers. This, allied to excessive number of persons per team, made the process of delimiting and appropriating in order to achieve interventions within territories unfeasible:

"It is reasonable to create reference teams, a Family Health team that is responsible for a population that lives in a territory within the catchment area of health centers. The problem is that this population is too large. So what happens? We are unable to actually take responsibility for it, [...] no matter how much we want to change, everything ends up being centered on demand, urgency, line" (camp15).

Curitiba, on the other hand, appeared to have a more consolidated process of working within territories, although it was still incomplete: 
"We always have to pay attention to the characteristics of each microarea [...] Someone who just goes along the avenue thinks that it's all the same. It's not the same at all! There are people at greater and lesser risk. We're always keeping an eye on those at greater risk. The problems are poverty, living and working conditions. The majority live from collecting recyclable materials in the street, so there's a lot of trash piled up, a lot of rubbish, rats, skin diseases, things like that. There's also drugs, alcohol, cocaine, crack, which are a big problem for the team." (ctba4)

A singular situation found in Campinas was the 20hour working week of approximately $60 \%$ of dentists, which was a factor contributing to almost exclusive dealing of the demand during their short stay in the basic health centers.

\section{Continuous education for the strategy development}

The investment of the Paideia Approach in team training appeared to have been strategic in the teams adhering to the reform proposed:

"I think that the 'turning point' in the health service network was due to many issues, a new government was taking up office; the health secretary trained the management team and health care teams, [...] This made us 'accomplices' of the project." (camp34)

During the interviews, it could be noted there was a visible slowing down in the capacity building of teams to expand or even maintain previous achievements:

"We had a lot of trainings, many people became specialists in public health. We expected that this work would be continued [...] I feel right now that we haven 't had any more training in Campinas... It stopped!" (camp31)

In Curitiba, FHS implementation was similar with regard to the investment in institutional partnerships to build teams' capacity. There were clearly strong partnerships with the Community Health Service of Conceição Hospital, in Porto Alegre, Southern Brazil, and the Department of Family and Community Medicine of University of Toronto, Canada.

From the viewpoint of the subjects studied, the training sessions proved to be shy and of questionable prioritization:

"The training sessions are more technical. In the health centers they're more directed towards the programs. I think there's not enough training in public health for the whole team. Training in epidemiology, planning, health policies. [...] I think that those working in the Family Health Program have to understand these things." (ctba7)

\section{Health promotion}

It was generally noticed among subjects a conceptual misunderstanding between health promotion and preventive actions for specific oral diseases:

"In public health service you have to act for the collectivity, you have to make an impact on a large number of people. The solution is prevention. This is what I consider to be the biggest stumbling block for health promotion." (ctba15)

Those who expressed understanding about health promotion and its relevance for changing the model reported operational difficulties in its application, either because of staff shortage or inadequate extra-sectorial articulation:

"I think that health promotion is a very far-reaching concept, it involves everything from providing a good service to improving patients' quality of life. There are some things we can intervene in, but others I think are more difficult. I think that today it's even hard to provide good quality medical care because the lack of materials and staff shortage means that we end up only seeing emergency cases." (camp13)

\section{Meeting users' demands and teams' ability to resolve them}

In both cities there are still difficulties in providing solutions for clinical care issues. Low PHD integrality was reflected in the reduced institutional capacity to offer more complex procedures, as seen in Curitiba:

"From the clinical point of view, how can we talk of integrality? A patient can even have a bone marrow transplant, but he can't have a periapical X-ray that costs $R \$ 5.00$ ? A patient has access to all medical exams and specialties [...] but a 15-year-old girl can't have root canal treatment of an incisor?" (ctba8)

The inexistence of district-level 24-hour emergency services was interpreted, in both cities, as a violation of civil rights. This service has never been available in Campinas and they had recently been closed down in Curitiba.

\section{DISCUSSION}

There are conditioning factors in the present study that should be explained. The results are restricted to the groups studied according to the methodological approach. At the most, discursive tendencies are established, but inferences as to the entire health system of the cities cannot be made. The participants' potential in providing qualified information and expressing, explicitly or implicitly, their "truths" as protagonists of the experiences analyzed is highlighted as a positive aspect. 
First, to discuss the analytical category of "access" in this study, it requires the recognition that the strategies implemented have contributed to the recovery of part of the oral health debt owed to the contingent of those excluded from health actions and services.

Improved user access to services is relevant. According to Moysés, ${ }^{13}$ there is a multiplicity of social and political determinants of "deprivation" and "exclusion." The author offers evidence that many diseases, including oral diseases, affect more deeply those who are deprived of access to public policies, among other factors.

In regard to the analytical categories of "humanization and autonomy," there was seen some evidence of a break off with technicism and biologicism. This has allowed health professionals to contextualize to a greater extent the complex determinants of the disease process. Barata ${ }^{2}$ discusses the Social Production of Illness model, showing that this approach uses explanatory models that make political, economic, and social determinants of health-disease explicit.

Focus groups held in Campinas show partial understanding of the principle proposed by the Paideia Approach with regard to the "construction of individual's autonomy." Campos 5 explains that the scope of healthrelated work is the production of health and development of the ability of the individuals involved in the process to reflect and act with autonomy.

The analytical category of "interdisciplinarity," understood as an interactive attitude of multiple areas of knowledge in the light of the individual's inability to respond to complex problems, refers to shared team strategies to find solutions to the problems presented individually and/or collectively. Through the experiences reported by both groups studied, it can be assumed an intermediate achievement of this dimension. The concept includes clinical coordination, but must also involve intervention in determinants and conditioning factors of the health-disease process; however, this was not clearly expressed in the experiences studied.

Local teams have partial autonomy to intervene in the analytical category of "territory". The observation of this social space is a pronounced differential in health service practice, as one can visualize the need of shared responsibility, bonds, and interventions with regard to conditioning factors of the health-disease process. Operational difficulties previously showed suggest the need for far-reaching discussions by health managers and technical staff so that the premise of "territorialization" is more than a mere idea and becomes part of FHS practices.

The analytical category of "training" aiming at capacity building proved to be problematical in both experiences studied, particularly in recent years. The analysis from the point of view of health managers, politically pressured by the growing demand for care, may at first justify the difficulty in making health workers leave their posts to take part in training processes. However, a health manager whose aim is to provide a solution for basic health services and be a qualified way of entering the health system, he/she is expected to make priority investments in health worker training, as they are the main actors of the process of change.

In the light of this study findings, it is stressed the importance of investing in the wide redefinition of the analytical category of "health promotion". Health promotion should be incorporated as a routine practice in PHD, replacing isolated clinical practice with broadened clinical pratice. ${ }^{6}$ Watt $^{16}$ ratifies that isolated education-preventive approaches have a limited effect and can, in contrast, accentuate inequalities. It also appeared to be necessary for health teams to have it more clear the meaning of health promotion, by translating it into real actions.

Finally, as for the analytical category of "demands", it can be confirmed that oral health is a real need of the Brazilian population. Campinas and Curitiba are not an exception. Manfredini ${ }^{10}$ presents consolidated data on the Participative Budget of the City of São Paulo (2002), showing that oral health was the second most requested service by the population, after expansion of the Family Health Program.

In conclusion, the two experiences have brought important advances for improving access, humanization of health care, integration of the health care team in providing responses to the users' clinical problems, among others. These are more than merely semantic modifications used to maintain former practices. 


\section{REFERENCES}

1. Andrade LOM, Barreto ICHC, Bezerra RC. Atenção Primária à Saúde e Estratégia Saúde da Família. In: Campos GWS, Minayo MCS, Akerman M, Drumond Jr M, Carvalho YM. Tratado de Saúde Coletiva. São Paulo: Hucitec; Rio de Janeiro: Ed. Fiocruz; 2006. p.783-836.

2. Barata RB. Social epidemiology. Rev Bras Epidemiol. 2005;8(1):7-17.

3. Campos GWS. A saúde pública e a defesa da vida. São Paulo: Hucitec; 1991.

4. Campos GWS. Saúde Paidéia. São Paulo: Hucitec; 2003.

5. Campos GWS, Minayo MCS, Akerman M, Drumond Jr M, Carvalho YMS, organizador. Tratado de Saúde Coletiva. São Paulo: Hucitec/Rio de Janeiro: Editora da Fiocruz; 2006.

6. Castro A, Malo M. SUS: Ressignificando a Promoção da Saúde. São Paulo: Hucitec/OPAS; 2006.

7. Chaves MM, Frenkel JM. Princípios Básicos para Organização de um Serviço Dentário Escolar. Rev FSESP. 1952;5(2):469-84.

8. Flick U. Uma Introdução à Pesquisa Qualitativa. 2.ed. Porto Alegre: Bookman; 2004.

9. Gatti BA. Grupo Focal na Pesquisa em Ciências Sociais e Humanas. Brasília: Líber Livro; 2005.
10. Manfredini MA. Saúde Bucal no Programa Saúde da Família. In: Dias AA, organizador. Saúde bucal coletiva: metodologia de trabalho e práticas. São Paulo: Editora Santos; 2006. p.43-73.

11. Mendes EV. Os Grandes Dilemas do SUS: tomo II. Salvador: Casa da Qualidade Ed.; 2001. p.71-154.

12. Minayo MCS. O desafio do conhecimento: pesquisa qualitativa em saúde. 9. ed. São Paulo: Hucitec; 2006.

13. Moysés SJ, Moysés ST, McCarthy M, Sheiham A. Intraurban differentials in child dental trauma in relation to healthy cities policies in Curitiba, Brazil. Health Place. 2006;12(1):48-64.

14. Narvai PC. Saúde Bucal Coletiva: caminhos da odontologia sanitária à bucalidade. Rev Saude Publica. 2006;40(Spec):141-7.

15. Watt RG. Introdução. In: Bönecker M, Sheihan A. Promovendo Saúde Bucal na Infância e Adolescência: Conhecimentos e Práticas. São Paulo: Ed. Santos; 2004. p.1-12.

16. Watt RG. From victim blaming to upstream action: tackling the social determinants of oral health inequalities. Community Dent Oral Epidemiol, 2007;35(1):1-11.

Article based on Nascimento AC's master's dissertation presented at the Pontifícia Universidade Católica do Paraná, 2007. 